ISSN 2598-3180 (Online)

JOURNAL OF MIDWIFERY

Re se archand Practice

Correlation Between Midwife Knowledge And Attitude, And District Health Service's Support In The Administration Of Vitamin A Supplementation For Postpartum Women In Working Area Of Puskesmas Seberang Padang And Puskesmas Pemancungan Kota Padang

\author{
Dyah Amalia Nauli, Ermawati, Yulizawati \\ Bachelor Of Midwifery Program FK-UNAND, Jln Niaga No.56 Padang City, 25127, Indonesia \\ Bachelor Of Midwifery Program FK-UNAND, Jln Niaga No.56 Padang City, 25127, Indonesia \\ Bachelor Of Midwifery Program FK-UNAND, Jln Niaga No.56 Padang City, 25127, Indonesia
}

\section{SUBMISSION TRACK}

Recieved: Mei 172017

Final Revision: Agustus 18, 2017

Available Online: Nopember 24, 2017

\begin{tabular}{llc} 
KEYWORD & & \\
\hline Attitude, & Knowledge, & Midwife \\
Postpartum, Support, & Vitamin A \\
supplementation
\end{tabular}

KORESPONDENSI

Phone: 075120120

E-mail:

\section{A B S S T R A A C T}

Current National Guidelines recommends that $100 \%$ of postpartum women receive 2 high doses of vitamin $\mathrm{A}$ capsules (200.000 IU) within 30 days after giving birth, so the mother can transfer vitamin A to baby through breast milk. Midwife as health worker have big role to achieve this program. This study was aimed to determine correlation of midwife's knowledge and attitude, and District Health Service's support in the administration of vitamin A supplementation for postpartum women.

This was a qualitative study with cross sectional study design among 32 midwives in working area of Puskesmas Seberang Padang and Puskesmas Pemancungan Kota Padang. The data was obtained using a structured questionnaire. Data were analyzed univariate by using frequency distribution and bivariate using chi square test.

Majority of midwife $(81,3 \%)$ gave vitamin A supplementation to postpartum women, there was a correlation between midwife knowledge with vitamin A administration in postpartum women $(\mathrm{p}=0,030)$, there was no correlation between midwife attitude and vitamin $\mathrm{A}$ administration in postpartum women $(\mathrm{p}=0,063, \mathrm{OR}=$ $7,667,95 \% \mathrm{CI}=1,035-56,770)$ and there was no correlation between district health service's support with vitamin A administration in the postpartum women $(\mathrm{p}=0,029, \mathrm{OR}=$ $11,250,95 \% \mathrm{CI}=1,125-112,535)$.

There is a tendency correlation between midwife's knowledge with vitamin A supplementation to postpartum women, no correlation between midwife's attitude with vitamin A supplementation to postpartum women and there is a correlation between district health service's support vitamin A supplementation to postpartum women. The health service is expected to improve the function of supervision and evaluation of midwife's performance 


\section{INTRODUCTION}

Puerperal period or commonly referred as postpartum is a period signed by the end of intrapartum where placenta and fetal membrane were born until the return of reproductive organs in non-pregnant conditions. In the postpartum period, woman has basic needs related to nutrition -taking vitamin A (200.000 SI)-, in order to give vitamin A to baby through breast milk (Kemenkes RI, 2013).

Vitamin A is one of the essential nutrients fat-soluble, stored in the liver and can't be produced by the body so it must be met from outside the body (Arisman, 2009). Vitamin A deficiency (VAD) in children can increase the risk of night blindness, susceptible to illness and the risk of death. Supplementation is one of the strategy in overcoming micro nutrient deficiency especially in women and children. Overall, only 48 percent of women received a postpartum vitamin A supplementation within a period of two months after delivery of the last child. The lowest level of supplementation among women with economic status is in the lowest wealth quintile (38\%) (Badan Pusat Statistik, 2013).

For infants who have not been able to meet their own nutritional needs, vitamin A intake will be obtained by infants from breast milk. Infants aged 1-5 months can't be given supplementation as 6 months's infants, toddlers and adults. Vitamin A supplementation in infants $(\leq 6$ months) was associated with an increased risk of swelling in infant fontanel (Imdad et al., 2016). As well as WHO recommendation that supplementation vitamin A in infants 0-6 months has no effect in reducing morbidity and death so vitamin A supplementation is not given as a routine intervention in infants aged 0-6 months (WHO, 2011).

Current national guidelines recommend that $100 \%$ of postpartum women receive two highdose Vitamin A capsules 200,000 SI no later than 30 days after delivery. Postpartum women are encouraged to take 2 vitamin A capsules because babies are born with low vitamin A reserves. Baby's need for vitamin A is high because it's needed for growth and increased endurance. 1 doses of vitamin A capsule $(200,000$ SI) on postpartum is only enough to increase vitamin A content in breast milk for 60 days, and if given 2 capsule (200.000 SI), its expected to add vitamin A content in breast milk until baby 6 months old (Depkes RI, 2009).
Based on Riskesdas data for 2007, 2010, and 2013, coverage of vitamin A capsule in Indonesia was $71.5 \%$ (2007), 69.8\% (2010) and $75.5 \%$ (2013). This shows a decrease in coverage from 2007 to 2010 and again increased in 2010 to 2013. For coverage of vitamin A capsule in West Sumatra Province decreased from 2007 to 2013. Based on Riskesdas data coverage is 73.5 $\%$ in $2007,71.6 \%$ in 2010 and only about $70.9 \%$ in 2013 (Kemenkes RI, 2013).

The coverage of vitamin A supplementation for postpartum women in 2015 in Padang increased by $95.19 \%$ (16,820 persons) from coverage in 2014 , which was only $93.1 \%(17,177$ people). However, in the working area of Puskesmas Seberang Padang, coverage of postpartum women receiving vitamin A was only $70.86 \%$ or only 248 postpartum women receiving vitamin A compared to a total of 350 mothers in the work area of Puskesmas Seberang Padang. This result is still very far from the average coverage in Kota Padang and the national coverage target is $100 \%$.

In the working area of Puskesmas Pemancungan located in one sub district with Puskesmas Seberang Padang, Padang Selatan sub-district, it has the highest coverage that is $100 \%$ on the percentage of postpartum mother who got vitamin A. Based on preliminary survey that has been done, the number of postpartum from January 2015 up to December 2015 is 362 people and the number of postpartum women who get vitamin A is 362 people. This means that coverage in Puskesmas Pemancungan has reached the target (100\%) (Dinas Kesehatan Kota Padang, 2016).

\section{METHODS}

This was a quantitative study using observational analyze with cross sectional design. Data collected by observation and questionnaire. Located in the working area of Puskesmas Seberang Padang and Puskesmas Pemancungan Kota Padang from November 2016 till September 2017. Population of this sudy is all of midwife in the working area of working area of Puskesmas Seberang Padang and Puskesmas Pemancungan Kota Padang. All of the population was made as sample Data analysis was performed using univariate (frequency distribution) and bivariate using chi square test $(p<0,05)$. 


\begin{tabular}{ccc}
\hline \multicolumn{1}{c}{ Variables } & $\begin{array}{c}\text { Frequent } \\
(\mathbf{n = 3 2})\end{array}$ & $\begin{array}{c}\text { Percentage } \\
(\%)\end{array}$ \\
\hline $\begin{array}{c}\text { Administration of } \\
\text { vitamin A }\end{array}$ & & \\
$-\quad$ Not Giving & 6 & 18,8 \\
- Giving & 26 & 81.3 \\
Midwife's knowledge & & \\
- Less & 6 & 18,8 \\
- Enough & 13 & 40,6 \\
- Good & 13 & 40,6 \\
Midwife's attitude & & \\
- Negative & 6 & 18,8 \\
- Positive & 26 & 41,3 \\
Health Service's & & \\
support & 13 & 40,6 \\
- Don't support & 19 & 59,4 \\
- Support & & \\
\hline
\end{tabular}

\section{RESULT}

Administration of vitamin $A$ in the postpartum is one of the care of obstetrics that must be done on every mother who has given birth giving 2 times. The first capsule is given immediately after delivery and the second capsule is given 24 hours after the first capsule. Vitamin A capsule given to postpartum is a red vitamin A capsule with a dose of 200,000 SI. The purpose of vitamin $A$ is to increase the levels of vitamin $A$ in the mother's body that will be useful to be given to the baby through breast milk because the baby was born with low vitamin A reserves. In addition, the benefits of vitamin $\mathrm{A}$ supplementation in postpartum mother, is to accelerate the condition of maternal recovery after childbirth and prevent infection in postpartum (Depkes RI, 2009).

The results of this study showed that most of respondents gave vitamin $A$ to postpartum woman $(81.3 \%)$, while the rest of respondents $(18.8 \%)$ did not give vitamin A to postpartum in the work area of Puskesmas Seberang Padang and Puskesmas Pemancungan Kota Padang (Table 1) . One of the role of midwives in the village in order to home visits to postpartum is as an effort to improve services and examination during childbirth. According to Kurniawati (2015), the implementation of vitamin A capsule is sometimes given when the village midwife makes a home visit. This is done by the village midwife if at the time of delivery there is no supply of vitamin A capsules to be given to postpartum immediately after delivery and waiting for supply of vitamin A capsules from Puskesmas.

\section{Table 1. Frequency distribution of vitamin A administration in postpartum mother, knowledge of midwife, attitudes of midwife and Health Service's support}

Midwives as health workers who play an important role in the provision of vitamin $\mathrm{A}$ in the postpartum should carry out their role according to the management guidelines of vitamin A supplementation according to the Department of Health Republik Indonesia (2009) is: (1) provide vitamin A capsules immediately after giving birth to labor practices; (2) provide vitamin A capsules by coordinating to local nutrition practitioners; (3) make a home visit to provide vitamin A capsules to postpartum and infant care; (4) records maternal cohort register data for pregnancy and maternity checks in private practice-as data collection of postpartum targets; (5) carry out the recording and reporting of requests and the provision of vitamin A capsules; and (6) provide reports of vitamin capsule to local nutrition practitioners.

\section{DISCUSSION}

\section{Correlation between midwife's knowledge in the administration of vitamin A supplementation for postpartum women}

Among $40.6 \%$ of respondents have sufficient knowledge about giving vitamin A to postpartum mother and as many as $40,6 \%$ others have good knowledge about giving vitamin A to nifas mother in working area of Puskesmas Seberang Padang and Puskesmas Pemancungan Kota Padang. The knowledge of midwives meant in this study is knowledge of the benefits of vitamin A, the target of vitamin A programs, and the benefits of giving vitamin A to postpartum.

The results showed that midwives who provided vitamin A in the puerperal mother with less knowledge than 50\%, midwives with sufficient knowledge $76, \%$, and midwives with good knowledge (100\%) gave vitamin A to postpartum (Table 2). Based on the statistical test, $p$ value $=0,030(p<0,05)$ means that there is a propensity correlation between midwife knowledge with vitamin A giving to postpartum mother in work area of Puskesmas Seberang 
Padang and Puskesmas Pemancungan Kota Padang.

Table 2. Correlation between knowledge in the administration of vitamin A supplementation for postpartum women

\begin{tabular}{ccccccc}
\hline & \multicolumn{3}{c}{$\begin{array}{l}\text { Vitamin A postpartum } \\
\text { administration }\end{array}$} & \multicolumn{1}{c}{ Total } \\
\cline { 2 - 5 } Knowledge & $\begin{array}{c}\text { Not } \\
\text { Giving }\end{array}$ & Giving & & \\
& & & & & & \\
\cline { 2 - 5 } & $\mathbf{f}$ & $\mathbf{\%}$ & $\mathbf{f}$ & $\mathbf{\%}$ & $\mathbf{f}$ & $\mathbf{\%}$ \\
\hline Less & 3 & 50 & 3 & 50 & 6 & 100 \\
Enough & 3 & 23,1 & 10 & 76,9 & 13 & 100 \\
Good & 0 & 0 & 13 & 100 & 13 & 100 \\
Total & $\mathbf{6}$ & $\mathbf{1 8 , 8}$ & $\mathbf{2 6}$ & $\mathbf{8 1 , 3}$ & $\mathbf{3 2}$ & $\mathbf{1 0 0}$ \\
\hline
\end{tabular}

As well as study by Herlina Samosir (2013), the midwife knowledge and coverage of vitamin A supplementation in the postpartum women had a significant association with $p$-value $=0.027$, means that well-informed midwives were 6.66 times more likely to achieve coverage of vitamin capsule $\mathrm{A}$ in the puerperal mother versus midwife with less knowledge. However, the results of this study are not in line with the study of Dewi (2010) which says that there is no significant relationship between knowledge of midwives in villages with coverage of maternal vitamin A $(p=0.7668)$ with the percentage of knowledgeable and low knowledge midwives are the same $(50.0 \%)$. The presence of this difference may be influenced by enabling factors such as midwives who do not always have vitamin A capsule preparations, or home visits that are sometimes not done because the distance to reach the remote postpartum home is the cause of the absence of vitamin A delivery in the puerperal mother in the village (Dewi, et al, 2010).

In this study, all midwives (100\%) with good knowledge will provide vitamin $\mathrm{A}$ in the postpartum (Table 2). Unlike the case with less knowledgeable midwives that only $50 \%$ who provide vitamin A in the postpartum. Most midwives are unaware that the first intake of the capsule after delivery and the second capsule is given 24 hours after the first capsule.

According to Notoatmodjo (2010), knowledge is the result of knowing that occurs after a person makes sense to a particular object where most of this knowledge can be obtained through education, self-experience and others, mass media and the environment. Notoatmodjo (2012) also adds that the level of knowledge is the main determinant of

the formation of one's actions and has an important role in the determination of attitudes.

According to Lawrence Green's theory in Notoatmodjo (2012), knowledge is part of predisposing factors related to one's behavior. Knowledge is needed as a motivation and an initial impetus for a person to foster self-esteem in action. So it can be said that knowledge is a stimulus to one's actions. It is also reinforced that knowledge-based behaviors will last longer than non-grounded behaviors (Notoatmodjo, 2003).

\section{Correlation between midwife's attitude in the administration of vitamin A supplementation for postpartum women}

Attitude is a reaction or response that is still closed from someone to a stimulus or object. Attitudes consist of components of belief (belief), ideas, and concepts to form a whole attitude and a tendency to act, but not yet an action. Therefore, midwives' beliefs about the benefits of vitamin A in postpartum women are needed to increase the coverage of vitamin A delivery of postpartum (Notoatdmojo, 2012).

The results of this study indicate that most midwives $(81.3 \%)$ have positive properties of vitamin $\mathrm{A}$ in the puerperal mother compared with midwives who have a negative nature of $18.8 \%$. However, this is not in line with the results of Hilma Yasni's (2013) study indicating that midwives have more negative attitudes $(56.3 \%)$ than midwives with a positive attitude toward vitamin A delivery in the puerperium (43.8\%).

Based on the statements contained in the questionnaire, most midwives reflect the negative nature of statements about their opinions regarding the administration of vitamin A 200.00 SI alone in postpartum women with good nutritional status $(88.1 \%)$ and most positive attitudes to statements regarding vitamin $\mathrm{A}$ on each of those who gave birth was twice (86.9\%).

The result of statistical test by using chisquare test showed that there was no significant correlation between midwife attitude and vitamin $\mathrm{A}$ in the puerperal mother with p-value $=0,063$ and $\mathrm{OR}=7,667$ (95\% CI 1.035-56,770). As shown in Table 3, in this study it was found that most of the midwives (88.5\%) with positive attitudes gave vitamin $\mathrm{A}$ in the postpartum compared to midwives with a positive attitude 
but did not give vitamin A to postpartum (11.5\%). This can happen because although the midwife is aware and confident of the benefits and importance of vitamin $\mathrm{A}$ in the postpartum they do not provide vitamin A because of the absence of a vitamin A capsule to be given to the puerperal mother. Conversely, in a midwife with a negative attitude but providing vitamin $\mathrm{A}$, it can occur because the midwife believes that giving vitamin $\mathrm{A}$ to the puerperal mother does not have a significant impact. However, since this is one of the national programs that midwives have to do in their care for postpartum, the midwife still gives vitamin A $2 \times 1$ capsules to every mother who has given birth

Table 3. Correlation between midwife's attitude in the administration of vitamin A supplementation for postpartum women

\begin{tabular}{cccccccc}
\hline & \multicolumn{9}{c}{$\begin{array}{l}\text { Vitamin A postpartum } \\
\text { administration }\end{array}$} & \multirow{2}{*}{ Total } & \multirow{2}{*}{$\begin{array}{c}\text { POR } \\
\text { Attitude }\end{array}$} \\
\cline { 2 - 5 } & $\begin{array}{c}\text { Not } \\
\text { Giving }\end{array}$ & \multicolumn{2}{c}{ Giving } & & & CI) \\
& f & $\mathbf{\%}$ & $\mathbf{f}$ & $\mathbf{\%}$ & $\mathbf{f}$ & $\mathbf{\%}$ & \\
\hline Negative & 3 & 50,0 & 3 & 50,0 & 6 & 100 & 7,667 \\
Positive & 3 & 11,5 & 23 & 88,5 & 26 & 100 & $(1,035-$ \\
Total & $\mathbf{6}$ & $\mathbf{3 1 , 7}$ & $\mathbf{2 6}$ & $\mathbf{8 1 , 3}$ & $\mathbf{3 2}$ & $\mathbf{1 0 0}$ & $56,770)$ \\
\hline
\end{tabular}

As well as other study by Dewi, et al (2010) which states there is no significant relationship between midwife attitudes in the village with coverage of vitamin A delivery in postpartum, meaning that supportive and non-supportive midwife's attitudes can't affect the achievement of scope administration of vitamin A capsule to postpartum mother $(p=0,3782)$. However, this result is contrary to the study by Hilma Yasni (2012) which is there was a significant relationship between attitude with vitamin A supplementantion in postpartum women ( $p=$ 0.041).

Positive and negative attitudes are closely related to someone's behavior. With good knowledge and a positive attitude will encourage the behavior of a person to a better direction. Similarly, the behavior of midwives in providing vitamin A in the postpartum women. Midwives with a positive attitude will be 7.67 times more likely to provide vitamin A in the puerperal mother than the midwife with a negative attitude.

\section{Correlation between district health service's support in the administration of}

\section{vitamin A supplementation for postpartum women}

The results of this study indicate that most midwives (59.4\%) get support from the Health Service (Table 1) while $40.6 \%$ of other midwives are not supported by the District Health Service for the provision of vitamin A in the postpartum in the work area of Puskesmas Seberang Padang and Puskesmas Pemancungan Kota Padang. In contrast of the Hilma Yasni's study (2013) where most midwives do not get support from the District Health Service (53.1\%).

Based on the results of research on District Health Service's support assessed through questionnaires that have been distributed and filled by midwives indicate that the most widely answered statement of midwives for District Health Service support is a statement about the Health Service and Head of Puskesmas that has explained in detail to all midwives about the time of the dividing month vitamin A. While the statement indicating the lack of support from Dibitbict Health Service is a statement about whether the Health Service and Head of Puskesmas always conduct coordination 10nerbings to monitor the evaluation of vitamin A coverage in the postpartum monthly with the result of $66.8 \%$ of the total 32 respondents.

Health Department's support is one of the strengthening factors for a health worker in this case, especially midwife in giving vitamin A to postpartum mother. The existence of support from agencies for a workforce will generate motivation and morale are real when compared with workers who do not get support from relevant agencies.

The results of this study indicate that most midwives (59.4\%) get support from the Health Service while $40.6 \%$ of other midwives do not get the Health Service's support for giving vitamin A to postpartum. Based on the result of statistical test, it was found that there was a significant correlation between the support of the Health Service with the provision of vitamin A in the puerperal mother with p-value 0,029 (p $<0.05$ ), OR 11,250 (95\% CI 1,125-112,535) means the midwife who received support The Health Department would be 11.25 times more likely to give vitamin A to postpartum than midwives who did not get support from the Health Service

As well as Hilma Yasni's (2013) study which shows the relationship between Health 
Service support and vitamin A in the puerperal mother with $p$ value $=0.001$, where most of the midwives who do not get Health Service support and do not give vitamin A to postpartum with a percentage of $88.2 \%$ compared with midwives who did not receive support and gave vitamin A to postpartum (11.8\%). If midwives do not get support from the Health Service's support, the chances of not providing vitamin $\mathrm{A}$ to postpartum women are increased 9-fold compared with midwives who have support from the Health Service.

The existence of support from certain parties will generate motivation for someone in doing a job. Dewi, et al (2010) in his research stated that the proportion of midwives in low motivated villages is at risk 1.8 times for not reaching coverage of vitamin A delivery in postpartum women compared with highly motivated village midwife. However, there was no statistically significant relationship between motivation and coverage of vitamin A delivery in postpartum women $(p=0.1847)$.

Kurniasari and Izzati (2013) in their study showed that the higher the perception of organizational support for an employee, the higher the employee engagement. What is meant by employee engagement is that employees consciously tie themselves to their work and when they are tied up they will hire and express themselves physically, cognitively and emotionally during the execution of their work. According to the theory of Rhoades and Eisenberger (2002) in Kurniasari and Izzati (2013) the perception of organizational support is the belief that employees have about the extent to which organizations value their contributions and care about their well-being.

Based on research by A Research by A Nurdiyan, YY Yulizawati, LE Bustami, D Iryani in 2014 stated that support of health service department in many health programme is important to run the programm throughly, without the support, monitoring and supervision by health service department the programme will not run properly. But they also said that the competency of Midwives to run the programme is also important because it is the responsibility of midwives to make sure that the programme is effective and efficient (A Nurdiyan, YY Yulizawati, LE Bustami, D Iryani, 2014)

Health Service's support is one of the strengthening factors for a health worker, especially midwife in giving vitamin A to postpartum mother. This support can be an explanation of the time and place of vitamin A division by the Health Service or the Head of the Puskesmas, providing postpartum vitamin A capsules for the midwife, a coordination meeting to monitor the coverage of vitamin A coverage in the postpartum monthly, midwives in carrying out vitamin A delivery to postpartum and attention to the success of nutrition and health programs conducted by midwives.

\section{Table 4. Correlation between district health service's support in the administration of vitamin A supplementation for postpartum women}

\begin{tabular}{|c|c|c|c|c|c|c|c|c|}
\hline \multirow{3}{*}{$\begin{array}{c}\text { Health } \\
\text { service' } \\
\text { s } \\
\text { support }\end{array}$} & \multicolumn{4}{|c|}{ Antenatal Care Visits } & \multirow{2}{*}{\multicolumn{2}{|c|}{ Total }} & \multirow{3}{*}{$\begin{array}{c}\text { POR } \\
(95 \% \\
\text { CI })\end{array}$} & \multirow{3}{*}{$\begin{array}{c}p- \\
\text { value }\end{array}$} \\
\hline & \multicolumn{2}{|c|}{$\begin{array}{c}\text { Not } \\
\text { giving }\end{array}$} & \multicolumn{2}{|c|}{ giving } & & & & \\
\hline & $\mathbf{f}$ & $\%$ & $\mathbf{f}$ & $\%$ & $\mathbf{f}$ & $\%$ & & \\
\hline Don't & 5 & 38,5 & 8 & 61,5 & 13 & 100 & 11,250 & \\
\hline support & & & & & & & $(1,125-$ & 0,029 \\
\hline Support & 1 & 5,3 & 18 & 94,7 & 19 & 100 & 112,535 & \\
\hline Total & 6 & 18,8 & 28 & 68,3 & 41 & 100 & ) & \\
\hline
\end{tabular}

\section{CONCLUSSION}

Provision of vitamin A in the postpartum is one of the care of obstetrics that must be done on every mother who has given birth giving 2 times. The first capsule is given immediately after delivery and the second capsule is given 24 hours after the first capsule. The vitamin A capsule given to postpartum is a red vitamin A capsule with a dose of 200,000 SI. Most midwives $(81.3 \%)$ gave vitamin A to postpartum mothers.

There is a tendency of correlation between midwife knowledge with vitamin A giving to postpartum mother, there is no correlation between midwife attitude with vitamin A giving to postpartum mother and there is relationship of Health Service support by giving vitamin A to postpartum in working area of Puskesmas Seberang Padang and Puskesmas Pemancungan Kota Padang. The Health Office is expected to improve the function of supervision and evaluation of midwife's performance and provide reward to the midwife so that the midwife is motivated to improve the health service to the community. 
ISSN 2598-3180 (Online)

JOURNAL OF MIDWIFERY

Re se arch a nd Practice

\section{REFERENCES}

A Nurdiyan, YY Yulizawati, LE Bustami, D Iryani. Analisis pelaksanaan kelas ibu hamil di Kabupaten Agam.. Journal of Midwifery 1 (1). 2014. P 45-54

Arisman. Gizi Dalam Daur Kehidupan: Buku Ajar Ilmu Gizi. Edisi Kedua. Jakarta : EGC. 2009

Badan Pusat Statistik. Suvey Demografi Kesehatan Indonesia 2012. Jakarta : Badan Pusat Statistik. 2013

Departemen Kesehatan RI. Panduan Manajemen Suplementasi Vitamin A. Jakarta : Departemen Kesehatan RI. 2009.

Dewi, VK, M Hakimi, dan A. Suhadi. Peran bidan di desa dan cakupan pemberian kapsul vitamin A pada ibu nifas. Berita Kedokteran Masyarakat. 26 (2). 2010. P 63-70

Dinas Kesehatan Kota Padang. Laporan Tahunan Tahun 2013. Padang : Dinas Kesehatan Kota Padang. 2014

Kesehatan Kota Padang. 2016

Imdad A, Ahmed Z, dan Bhutta ZA. Vitamin A supplementation for the prevention of morbidity and mortality in infants one to six months of age. Cochrane Database of Systematic Reviews. Issue 9. 2016.

Kementerian Kesehatan RI. Buku Saku Pelayanan Kesehatan Ibu di Fasilitas Kesehatan Dasar dan Rujukan. Pedoman Bagi Tenaga Kesehatan. Edisi Pertama. Jakarta : Kementerian Kesehatan Republik Indonesia. 2013.

Indonesia. 2013.

. Riset Kesehatan Dasar 2013. Jakarta : Kemeterian Kesehatan Republik

Kurniasari, R dan U.A. Izzati, Hubungan Persepsi Dukungan Organisasi dengan Employee Engagement Pegawai Negeri Sipil Dinas Kesehatan Provinsi Jawa Timur. Universitas Negeri Surabaya. Character. Volume 02 Nomor 01 Tahun 2013. 2013.

Notoatmodjo, S. Ilmu Perilaku Kesehatan. Cetakan Pertama. Jakarta : Rineka Cipta. 2010.

Cipta: 2012 .

Promosi Kesehatan dan Perilaku Kesehatan.Cetakan Pertama. Jakarta : Rineka

Saifuddin, AB. Buku Panduan Praktis Pelayanan Kesehatan Maternal dan Neonatal. Edisi Pertama. Cetakan Kedua. Jakarta : Yayasan Bina Pustaka Sarwono Prawirohardjo. 2002.

Samosir, H. Hubungan Pengetahuan Bidan Tentang Vitamin A dengan Cakupan Pemberian Vitamin A Pada Ibu Nifas di BPS Wilayah Kerja Puskesmas Tegal Sari Kecamatan Denai Tahun 2013. Universitas Sumatera Utara. Medan. 2013. 
Varney, H, JM. Kriebs dan CL. Gegor. Varney's Midwifery. $4^{\text {th }}$ Ed. Jones and Barlett Publishers, Inc. Sudbury. Terjemahan Mahmudah, L dan G. Trisetyati. 2007. Buku Ajar Asuhan Kebidanan. Ed. 4. Vol. 2. Jakarta : EGC. 2004. 
